\title{
Establishing research legitimacy in the contested political ground of contemporary Northern Ireland
}

Knox, C. (2001). Establishing research legitimacy in the contested political ground of contemporary Northern Ireland. Qualitative Research, 1(2), 205-222.

Link to publication record in Ulster University Research Portal

\section{Published in:}

Qualitative Research

Publication Status:

Published (in print/issue): 01/01/2001

\section{Document Version}

Author Accepted version

\section{General rights}

Copyright for the publications made accessible via Ulster University's Research Portal is retained by the author(s) and / or other copyright owners and it is a condition of accessing these publications that users recognise and abide by the legal requirements associated with these rights.

\section{Take down policy}

The Research Portal is Ulster University's institutional repository that provides access to Ulster's research outputs. Every effort has been made to ensure that content in the Research Portal does not infringe any person's rights, or applicable UK laws. If you discover content in the Research Portal that you believe breaches copyright or violates any law, please contact pure-support@ulster.ac.uk. 


\title{
Qualitative Research
}

http://qrj.sagepub.com

\section{Establishing research legitimacy in the contested political ground of contemporary Northern Ireland}

\author{
Colin Knox
}

Qualitative Research 2001; 1; 205

DOI: $10.1177 / 146879410100100206$

The online version of this article can be found at:

http://qrj.sagepub.com/cgi/content/abstract/1/2/205

\author{
Published by: \\ (S)SAGE \\ http://www.sagepublications.com
}

Additional services and information for Qualitative Research can be found at:

Email Alerts: http://qri.sagepub.com/cgi/alerts

Subscriptions: http://qri.sagepub.com/subscriptions

Reprints: http://www.sagepub.com/journalsReprints.nav

Permissions: http://www.sagepub.co.uk/journalsPermissions.nav

Citations http://qri.sagepub.com/cgi/content/refs/1/2/205 


\title{
Establishing research legitimacy in the
} contested political ground of contemporary Northern Ireland

COLIN KNOX

University of Ulster

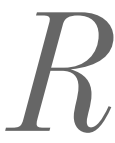

Qualitative Research Copyright (C)2OOI SAGE Publications (London,

Thousand Oaks, ca and New Delhi) vol. I(2): 205-222. [I468-794I (200IO8) I:2 205-222; OI8244]

\begin{abstract}
A B S T R A C T Despite the plethora of literature on the macro politics of Northern Ireland, there is a dearth of material on grassroots activity, in particular the dynamic between communities and paramilitary groups which enforce 'law and order' in working-class areas. Political progress in the form of the Belfast Agreement (1998) has overshadowed the ongoing level of violence at the micro level and the voice of victims remains unheard in the search to attain a greater goal - a long-term political and constitutional settlement. This article examines the methodological difficulties in establishing research legitimacy in the contested political arenas of Northern Ireland. It considers issues of access, establishing the researchers' bona fides, openness and transparency, language and personal security, and offers some insights into research in sensitive topics.
\end{abstract}

KEY W O D S : beatings, paramilitary, punishment, victims, violence

\section{Introduction: research paramilitary violence}

Northern Ireland is replete with literature on political violence which concentrates on two broad areas - firstly, trying to establish the facts or data about the levels, distribution and sources of violence (Murray, 1982; Poole, 1993, Sutton, 1994; Fay et al., 1999) and, secondly, examining the causes of - or motivation for - violence (Hillyard, 1985; White, 1993; O'Duffy, 1995; Sullivan, 1998). What is largely absent, however, is research on the nature of the relationship between paramilitary groups and the communities over which they exert social control (Kennedy, 1995: 67). There are, however, notable exceptions. Cavanaugh (1997), in an ethnographic study undertaken in loyalist and republican communities in Belfast, posited the community, not as a passive entity, but integral to the analysis of political violence in Northern Ireland. She concurred with research undertaken by 
Burton (1978) who argued that paramilitaries and their communities had a 'see-saw' relationship, and that to describe it as one forged through 'naked force' was too simplistic. Silke's work $(1998,1999)$ also provides insights into the relationship. He argued that the activities of paramilitaries revolved 'around a practical need to control criminal behaviour as perceived by the community, and to control behaviour within that community which may threaten the authority of the paramilitaries' (1998: 151).

The complexities of the community-paramilitary relationship are also obvious from a study by Brewer et al. (1998) which looked at the role played by local communities in civil unrest and crime management. The researchers challenged some preconceptions about informal policing by paramilitaries as a means of social control in a study of two areas in Belfast. In this study, they found localized evidence of the extended family network, a sense of neighbourliness and community identity "which extends beyond the policing role of the paramilitary organisations'. In fact, they argued the role which paramilitaries play in local crime management 'is heavily conditional upon the survival of community structures' (Brewer et al., 1998: 576, 581).

The role that communities play in our understanding of political violence in Northern Ireland prompted further research by the author. The substance of this research is not however the subject of this article, rather the methodological issues associated with undertaking sensitive community based research, specifically establishing research legitimacy within the contested political context of Northern Ireland. Our discussions centre on issues associated with conducting qualitative research involving, inter alia, victims $(n=40)$ of 'punishment' beatings and shootings, focus group work within loyalist and republican communities $(n=4)$ 'controlled' by the paramilitaries, interviews with political parties $(n=12)$ and statutory/ voluntary organizations $(n=43)$ directly or indirectly involved with victims of paramilitary violence. Although the issues dealt with are personal reflections on researching paramilitary violence they may have wider implications for those undertaking 'sensitive fieldwork' elsewhere.

Other researchers on Northern Ireland have addressed related methodological issues in conducting fieldwork. Jenkins' (1984: 152) account, for example, of doing anthropological fieldwork in a Belfast housing estate highlights the importance of the identity of the researcher in the eyes of his/her research subjects and its impact, positively or negatively, on access. Sluka's (1989) ethnographic research within the republican/nationalist Divis Flats area of Belfast draws attention to a number of issues related to conducting sensitive research. Writing about volatile political subjects can leave the researcher open to claims of being an 'apologist or propagandist rather than an objective social scientist' (Sluka, 1989: 15). Other problems include the very real dangers (from paramilitaries and the security forces) involved in doing the research, suspicion over the researcher's identity, emotional involvement/empathy with the subjects, ethical concerns about 
the safety of informants and the potential of the data gathered being used by 'counterinsurgency specialists and other disreputable agencies bent on ultimately harming the people studied by the ethnographer' (Sluka, 1989: 37). Significantly there is also disagreement over methodological approaches. Feldman's (1991: 12) research on the cultural construction of violence through oral histories in Northern Ireland between 1969 and 1986 points out that in a culture of political surveillance, participant observation is at best an absurdity and at the least a form of complicity with those outsiders who surveil'. He argued that an ethnographic approach prevented researchers from conducting research in both communities in Northern Ireland - they become too closely identified with one side, and as a result lacked legitimacy in the other. Whilst these researchers raise general issues which inform research methodology in the contested political arena of Northern Ireland, we are mindful of Brewer's conclusions on police research in the same context, that sensitivity is highly situational and researchers need to consider 'what they believe to be controversial and sensitive but also what their respondents, potential gatekeepers, and the community at large might consider to be sensitive about the research' (Brewer, 1993: 143). Similarly, Alty and Rodham (1998) suggest that research within sensitive areas requires flexibility, and demands practical solutions that are not always linked to ethical dilemmas. Before turning to a discussion of these methodological issues it is necessary to set the substantive research in context.

\section{The research context}

The euphoria unleashed by the signing of the Belfast Agreement and the endorsement by its signatories of their 'total and absolute commitment to exclusively democratic and peaceful means of resolving differences' (Belfast Agreement section 4:1, 1998) created the impression that violence had been eschewed in Northern Ireland. Almost three years later the evidence suggests that this is far from true. It is the case that the worst manifestations of the conflict - sectarian killings and bombings - are declining. In 1999, for example, seven civilians were murdered, the lowest figure since the 'troubles' began, and the first year ever that there were no security force fatalities (Royal Ulster Constabulary [RUC] statistics: Northern Ireland Office, 2000). This, however, ignores an insidious and ongoing level of paramilitary violence inflicted on working-class communities referred to as 'punishment' beatings and shootings or the informal criminal justice system. Paramilitary groups see themselves as community protectors; their actions aimed ostensibly at maintaining 'law and order' through tackling petty crime such as car theft, joyriding, burglary and drug dealing. Up to the end of June 2000 police statistics show that there have been 2,303 shootings (an average of 85 per year) and 1,626 beatings (an average of 90 per year) since 1973 and 
1982 respectively, when figures were first recorded. ${ }^{1}$ These statistics however are thought to grossly under-estimate the true extent of the problem. Those subjected to beatings and shootings are fearful of involving the security forces in case of paramilitary reprisal and hence there is large scale underreporting.

Paramilitary perpetrators exact community 'justice' using pick-axe handles, hockey and hurley sticks, baseball bats, steel rods and hammers. Other forms of 'punishment' include dropping heavy concrete blocks on limbs and using power tools on bones. Surgeons in the fracture clinic at the Royal Victoria Hospital in Belfast, for example, report that 'following the cessation of violence there has been an increase in the level of injuries occurring in those undergoing paramilitary punishment' (Nolan et al., 1999, emphasis added). Their study of treating victims showed that those who had been shot with pistols, resulting in open injuries, suffered much less damage to soft tissue and bones than those who had been beaten. The brutal reality is that is 'better' to be shot than beaten.

From the research undertaken for this study three principal reasons are advanced by communitarians for the existence of the so-called informal criminal justice system. First, particularly in republican areas, there is an absence of an adequate policing service. The RUC has no legitimacy amongst republicans, and their communities would not normally involve the police in dealing with crimes in their areas. Republicans claim that the RUC are prepared to tolerate at best, or encourage at worst, crime in their communities as a way of undermining the 'republican struggle'. Police are therefore willing to 'trade' dropping charges of joyriding, drug dealing, burglary etc. in return for low-level intelligence gathering on known republicans. In loyalist areas, objections to involving the police are more to do with keeping the RUC out of communities where drug dealing, racketeering and illegal drinking dens/clubs are commonplace. Second, there is a rising level of 'anti-social behaviour' and petty crime, particularly in working-class areas. This is evidenced in crime and victimization statistics, which show that those from an unskilled social class background are most vulnerable and feel their quality of life is particularly affected by fear of crime (Northern Ireland Office, 2000). A Police Authority (PANI) report which monitored the performance of the RUC during 1998/9 found "many categories of crime are on the increase while police performance in tackling this has not always been as effective as anticipated' (PANI, 1999: 9). In the absence, therefore, of a legitimate police force and/or because people are discouraged from seeking RUC involvement, communities turn to paramilitaries to secure a prompt, visible and effective response to crime in their areas. Hence, local people living in fear of crime endorse paramilitary 'punishment' beatings and shootings. Third, the formal criminal justice system within these communities is perceived as slow, ineffectual and soft on crime. In a society where violent conflict has been the norm for over 30 years, it is not surprising 
that the time taken to process offenders, the necessary safeguards in the legal system, and the standard of proof required for conviction is seen as no match for summary justice meted out by paramilitaries. This formed the backcloth for the research on the relationship between paramilitaries and communities in Northern Ireland. We now consider methodological issues in conducting the research under five key headings: access to victims of 'punishment' beatings; establishing our bona fides; openness and transparency; nomenclature; and personal security.

\section{Accessing victims}

One of the most obvious methodological problems is securing access to those who have been subjected to paramilitary beatings. Making contact with community organizations with whom the researchers had previous experience seemed a useful starting point for the research. Whilst community workers were aware of a number of victims, their role in brokering contact met with limited success. What became clear was that the same community organizations had been the target for complaints about those involved in antisocial behaviour and onward referral of these complaints to paramilitaries. It should not have been too surprising therefore that 'punishment' victims felt unwilling to co-operate for research purposes with community organizations they suspected of 'running to paramilitaries' about them. This was not wholly unproductive and gave us access to interviews with, for example, a father and son who had been beaten in a mistaken identity case and community volunteers/workers who had themselves been beaten or shot.

A typical account given by a victim illustrates the sensitivity of the topic:

The paramilitaries put a bag over my head and bundled me into a black taxi. As they were driving me away I started to cry and they told me to 'fuck up, we just want to have a word with you about hooding'. When they stopped they threw me face-down on the ground and told me to shut my eyes tight. They took the bag off my head and told me to put my hands by my side. They grabbed my ankles and I heard a click and a bang and my leg just heated up - it was like a hot poker going through your leg. I started to scream. They were going to hit me a boot in the head, they told me to fuck up and then they shot me in the other leg. Then I started to scream more. I looked up shortly afterwards and there was nobody about. I was lying there screaming and shouting 'help, help, I've been shot, I need an ambulance' and a woman came out of her back garden and seen me lying there. Then I felt a wee bit faint. I wet myself as well. I asked for a glass of water but nobody would give me one because all the dirt was in my throat. The next minute my legs were being strapped and I was screaming more because I didn't want to be touched.

In the hospital they gave me morphine to knock me out. The next day the doctor said to me: "The good news is that you are going to walk again. The bad news is that there's a bullet in your right leg and we can't get it out. It's lodged there and if we try to get it out we're going to hit an artery and we won't be able to stop the bleeding.' My nerves have just been shattered from it. I have 
nightmares every night. If I'm sitting in a room and see a couple of fellas staring at me, my hands sweat because I think they're in the paramilitaries, and I get paranoid. (Interview with victim of 'punishment' shooting, December 1999).

When access was proving particularly difficult and slow, however, one suggestion was to visit victims admitted to hospital for injuries resulting from paramilitary attacks, the researcher's equivalent of ambulance chasing. Media coverage of these incidents often carried footage of victims in hospital beds. Whilst this had the clear potential of raising awareness of the horrific nature of these incidents on a scale beyond the capacity of our research, there was also the danger of sensationalism. Our own predisposition was therefore to reject this possibility for access on the grounds that it could exacerbate the victim's distress, recounting the incident so soon after the event and we suspected payments were made for the interviews, which may have influenced the motivations of the respondents. ${ }^{2}$

The most productive source of access, however, proved to be via the Probation Board for Northern Ireland, an executive non-departmental public body whose aim is to help prevent re-offending. Their day-to-day business brought them into contact with young people, a number of whom had been 'disciplined' by the paramilitaries for 'anti-social behaviour'. Support for the research was secured at the senior level of the organization and a letter of endorsement sent to area probation managers. Thereafter, the researchers made contact with local probation officers for referrals. Their professional interest in the topic and access to a 'captive' client base proved fruitful. A number of probation officers had to deal with the consequences of paramilitary violence for young people and were keen to assist with research that could help to address its causes. Their brokerage role also carried certain credibility and cultivated trust with those willing to be interviewed which would have been difficult for us as researchers ex ante to secure.

The issue of accessing victims raised a number of ethical concerns for the research. Given the difficulties encountered in securing interviews with this group, the role played by the Probation Board was significant for the research project. A key ethical concern here must be the willingness of (largely) young men on probation to become involved in the research. Although probation officers assured informants that their participation was voluntary and their views confidential, the nature of the relationship between the two parties could have influenced their willingness to take part. Moreover, since the initial approach to the potential interviewees required some explanation as to the purpose of the research, probation officers (in good faith) had probably only a superficial grasp of what was involved. An obvious ethical concern here was whether the informants really knew what they were agreeing to, or was their consent to participate fully informed? Although each interview began by restating the objectives of the research and made reference to the topics that would be covered during the session, it was going to be more difficult at that stage for interviewees to withdraw their co-operation - none did. 
Another key ethical concern was whether victims engaging in the research were exposed to physical and mental harm. In the case of the former, interviewees were specifically asked not to mention names, locations or incidents during taped interviews, which would connect them to the qualitative data and could result in paramilitary reprisal or perhaps police action. Inevitably, in the course of interviews, some did. Feldman (1991: 12), in his research work on Northern Ireland, claimed that he became 'expert in demonstrating that there were things, places and people I did not want to know'. Jenkins (1993: 248) makes a similar point in the same context when he suggested that the researcher "is limited in terms of what people are prepared to divulge, on the one hand, and what it is sensible to know on the other'. Special arrangements were therefore put in place for the storage, transcription and access to tapes that were subsequently edited to remove any information that could connect the informant. In terms of mental stress, the quotation from the 'punishment' victim above aptly illustrates the long-term psychological impact of these incidents. Recounting their stories, on occasions, led to highly charged emotional accounts of very brutal encounters. Without counselling experience, the researchers felt inadequate to support interviewees through this experience.

\section{Establishing our bona fides}

Beyond access, the first requirement for researchers in undertaking fieldwork of this nature is to establish their bona fides within the constituency. A key component of this is the need to demonstrate objectivity in one's approach to the study. Sluka (1989) in his research noted that no-one can study a community in Belfast first-hand without becoming emotionally and morally involved and, as such, claims of total objectivity are spurious. He pointed out, however, that the researcher can be morally and emotionally involved with those he or she studies without this necessarily constituting bias or prejudice.

If objectivity does not refer to some dubious and facile claim to absolute neutrality and disinterested detachment, which it does not, then one can have values and be emotionally involved with those one studies and still be objective. (p. 14)

Sluka's work was confined to one constituency (republican/nationalist) in Northern Ireland and concerns about perceptions of objectivity were more salient in our work which researched both communities. There is deep-rooted hostility between the republican and loyalist paramilitaries and we, as researchers, had to be aware of not being seen to favour one constituency at the expense of the other. There was immediate suspicion about the ulterior motives of this research, which had the potential to block access at worst or severely curtail data gathering. Three tactics were useful in addressing this issue. 
First, it was crucially important to obtain 'approval' from key stakeholders. It is widely accepted in Northern Ireland that certain political parties have a direct line into the paramilitaries despite official denials or obfuscation about the nature of the relationship. Undertaking the research therefore required the imprimatur of paramilitaries or, at the very least, making them aware that fieldwork of this nature was being undertaken and its purpose. Apart from issues of access, there were important safety considerations for the fieldworkers. 'Working the streets' in well-known paramilitary enclaves without their knowledge would be to invite trouble. Their 'approval' was secured by contacts with key political representatives in both communities, ostensibly to 'keep them informed' of our work, in reality it amounted to securing their unofficial endorsement. As Lee (1995) notes, paramilitary groups in Northern Ireland satisfy themselves that researchers working in 'their' areas have no involvement with security forces.

The second useful tactic in establishing our bona fides was to stress the independence of the research. One important aspect of this was the source of funding for the research. Those approached for interview would frequently enquire, or indeed we would volunteer the information in an effort to stress our own independence, about the research sponsors. Although the project sought government (Northern Ireland Office) funding and did not secure it, this actually proved to be an advantage for fieldworkers. As the government is perceived by some of our interviewees to be a key protagonist in the conflict, to have secured funding from this source would have been tantamount to 'supping with the devil' and our motives would have been questioned. The fact the research was funded by an academic source (the Economic and Social Research Council [ESRC]) and located within a university, in itself, suggested an independence which might otherwise have been difficult to secure.

The third tactic was a methodological one. Part of the process of building street credibility and establishing the bona fides of the researchers comes through research leads. Gaining access to key interviewees and using 'snowballing' to extend the network may not only improve the source of informants, but also reflect positively on the credibility of the researchers. In other words, if interviews have been secured with influential stakeholders, this has a reinforcing effect on the 'weight' of the research and, vicariously, those involved in undertaking it. The process extends to building relationships with key informants over a period of time and allowing rapport to be established incrementally, an experience similar to Brewer's research in gaining the confidence of RUC interviewees suspicious of his motives (Brewer, 1993).

Undertaking qualitative research required interviews with informants who may personally and/or through the organizations they represent condone, actively support or have engaged in political violence in the past - a number of ex-prisoners (some convicted of murder(s), for example) are now involved in community restorative justice projects. Interviewers cannot be seen to identify with actions of paramilitaries in a disingenuous tactic to secure their 
co-operation. It would be easy to feign empathy with their suggestions of bravery, protectiveness, toughness, fighting for the cause of the underdog in an unjust 'war' - over-identification with subjects (Fielding, 1990). Conversely, researchers must guard against expressing repugnance of interviewees whose behaviour/actions they find an anathema - this is unlikely to secure their co-operation in data gathering. Lee (1995) contends that this type of concealment verges on deception:

Complete neutrality is probably impossible. It is unlikely that one's sympathies will be engaged to an equal degree by all parties to the conflict ... Often when researchers proclaim their neutrality, they are in fact concealing their own sympathies. By doing so, they deceive at least some of those in the setting. A number of writers have argued that deception of this kind is permissible, indeed laudable, in highly stratified, repressive, or unequal contexts (p. 23).

There is nothing new in conducting interviews with respondents whose views researchers disagree with; what was important in this research was the fact that remaining non-judgemental could be much more difficult to achieve and the independence of the researcher was frequently challenged.

\section{Openness and transparency}

When researching paramilitary violence there is a need for openness and transparency in dealings with individuals and groups who have been (and continue to be) in conflict with, and retain a measure of distrust towards, each other. This must be balanced against the requirement to maintain confidentiality. There is a fine line between these requisites in this type of research and not everyone agrees that they are requisites. Tunnell, for example, argued in his research on violent crime in America that he was prepared to lie to 'minimize risks to research participants, to myself and to the success of the research' and 'to deceive others who attempted to exercise their power over the research and participants' (Tunnell, 1998: 209, 213). He claimed that the nature of such research demanded this. "The methodologies of "muddy boots" and "grubby hands" implicitly means taking sides, recognizing the politics of one's research, engaging in impression management, and hedging the truth' (Tunnell, 1998: 208). We could not agree with such an approach in the dangerous research environment of Northern Ireland where it is important for the safety of the researchers to be open and transparent. Sluka (1989: 26, 28), for example, argued that he tried to be 'as honest and straightforward as possible' during his fieldwork in Belfast, in fact to make himself so conspicuous that the IRA and the INLA could not possibly think of him as a spy. Our own commitment to openness and transparency has been shaped where necessary by discretion and the need to maintain a low profile, given that our research straddled the political divide. 
One approach which proved useful in establishing transparency in the research was an informational leaflet containing details of the project (aims, objectives, methodology, etc.) which was sent to participants in advance of an interview. This would often form the opening gambit for the face-to-face meeting and allowed the researchers the opportunity to expand on the substance of the project, and the interviewee to follow-up with questions about the research. The facts contained therein were sufficiently broad to assure interviewees that the research was cross-community with clear public policy outcomes.

The aim of maintaining openness and transparency did not, however, extend to actively publicizing the research. The topic of paramilitary 'punishment' beatings has a certain journalistic appeal. The widest-read Belfastbased newspaper (The Belfast Telegraph), for example, ran a feature entitled 'Halt the Torture' which gave personal accounts of those who had been attacked. Whilst the intentions of the journalists were undoubtedly to heighten public awareness of the issue and perhaps bring pressure to bear on the paramilitaries, we avoided making any contribution to the public debate. Any such commentary could have been construed by potential interviewees as taking a position on the issue, which would have proved counterproductive in conducting further fieldwork. Moreover, 'solutions' were being sought by journalists to address this 'problem'. Apart from the research being incomplete at that stage, explaining the nuances of the informal criminal justice system did not make for succinct journalistic sound-bites. Openness and transparency were therefore managed in a way that was not damaging to the aims and objectives of the project - in short, we adopted a measured sensitivity approach.

This measured degree of openness still left the project vulnerable to seemingly innocuous requests for information from sources that could be seen by some of our informants as tendentious. The Northern Ireland Office, for example, invited us 'to share perceptions of the problem' with their senior civil servants. The invitation was treated with some cynicism as it coincided precisely with the politicization of the issue when 'punishment' beatings threatened to stymie the implementation of the Belfast Agreement, prisoner releases in particular. As researchers, having access to interviewees in both the Northern Ireland Office and the RUC was a crucial part of the fieldwork and indeed we rely on these public bodies for endorsement and/or implementation of the public policy recommendations that emerged from the research. This, in turn, might create an expectation amongst these interviewees that we should share sensitive data gathered from other sources. To cross this line from researcher to informant, however, posed a dilemma. As researchers, we did not wish to act in bad faith - on the one hand keen to secure interviews with senior civil servants and police officers but, on the other, unwilling to divulge information on the substance of the research. 


\section{Nomenclature}

A key issue in researching paramilitary violence is the political connotations of the language used by the researchers. This has wide-ranging implications ranging from gaining access to targeted interviewees through subsequent conduct of the fieldwork, to the publication and dissemination of the findings. So emotive is the use of language that key words can potentially restrict access or give the impression during fieldwork of bias on the part of the investigator. The nomenclature of the researcher is replete with politically sensitive words. The most common pitfall is making reference to 'Northern Ireland'. Northern Ireland is the name of the formal political unit created by the Government of Ireland Act (1920), and Ulster or 'historic Ulster' is the province made up of nine counties of pre-1920 Ireland. With clear political overtures, nationalists use the term 'the Six Counties' or 'the North of Ireland' and unionists prefer the term 'Ulster' (McGarry and O'Leary, 1995: 509, glossary and terminology). Even the seemingly unproblematic use of labels such as 'unionist' and 'nationalist' is not always clear-cut (Whyte, 1990: 18). There is a distinction between those who see their loyalty primarily to Ulster and those whose allegiance is to the United Kingdom as a whole - the broad difference between 'loyalists' and 'unionists'. Similarly, those who seek a united Ireland by constitutional consent would describe themselves as 'nationalists' compared with 'republicans' who defend the use of force to achieve the same objective. From this minefield of politically sensitive terms emerges a host of derivatives. Nationalists and unionists refer to the second city of Northern Ireland as Derry and Londonderry, respectively. The combined term 'Sinn Féin/IRA' is now part of unionist political parlance to emphasize what they see as the inextricable link. The use of the Irish language is not uncommon in oral preliminary welcomes at interviews or written communications with nationalists or, more commonly, republicans.

The key question for those researching a topic with such obvious political sensitivities as paramilitary violence is whether to adopt the language known to be most acceptable to the interviewee. In other words, should the researcher adapt to different political settings in the absence of a neutral language? This question is particularly pertinent for local researchers who would be expected to understand the nuances of language and reflect this in their research questions. Outsiders are given some latitude. Our experience of research in other conflict countries such as Israel in which we referred to the site in East Jerusalem where Israelis are building homes on contested land as Har Homa (Hebrew) as opposed to Jabal Abu Ghneim (Arabic) brought swift but polite correction from Palestinian interviewees. Indigenous researchers would, we suspect, have been given short shrift.

Aside from the use of general political labels, this particular research project generated its own difficulties with research language. In studying 
paramilitary violence a convenient and pragmatic shorthand was the use of the terms 'perpetrators' and 'victims'. Put simply, paramilitaries carried out punishment beatings and those at the receiving end were victims. Therein lie a number of problems. The use of the term 'punishment', as Kennedy (1995) suggests, is value-laden in that it carries a presumption that the victim is somehow deserving of what is meted out by the paramilitaries. Moreover, it can conjure up an image of chastisement, threatening behaviour and minor physical violence. This point is taken up in a parliamentary debate on the issue:

The term 'punishment beating' sounds like a modest extension of Neighbourhood Watch - at the very worst some vigilante group modestly beating up drug dealers or vandals. Let us make it absolutely clear what is going on in Northern Ireland. We are talking of mutilation, and of beatings in which every bone in the victim's body is deliberately broken. It is intimidation of the very worst sort, and often leads to exile (Andrew MacKay, Conservative Opposition Spokesperson on Northern Ireland: Parliamentary Debate - House of Commons 27 January 1999).

In a similar vein, the use of the term 'victim' can disempower those who have been the subject of such attacks and beatings. There is what Beattie and Doherty (1995) describe in their accounts of paramilitary-related violence as the 'subtle negotiation of blame' away from the perpetrator to the victim. In a television interview by the hospital bedside of a 13-year-old boy beaten by the paramilitaries, for example, his mother stated while he might be 'bad' like any other local young person, 'other kids do it and they don't get batons taken to them'.

Such attacks do not recognize due process, and summary justice carried out in this way, based upon accusation and hearsay, has led to notable 'mistakes'. John Brown, an 80-year-old Belfast senior citizen, was shot in the knees and ankles by a Provisional Irish Republican Army (PIRA) team who mistakenly identified him as a convicted paedophile. They subsequently apologized for their actions. In Strabane a masked squad of paramilitaries burst into a man's house and beat him with baseball bats and an iron bar before realizing their intended target lived next door. They regrouped and inflicted multiple injuries on his neighbour.

The term 'victim' has also become politicized. A row broke out when the Minister for Victims in Northern Ireland met with families of PIRA members shot dead in 1987 by the SAS (Special Air Service) at Loughgall. The pressure group, Families Acting for Innocent Relatives (FAIR), claimed 'these people were not victims - they caused the troubles' (Thornton, 1999: 6). Sinn Féin refuted this and argued no section had a monopoly on suffering and the grief of all relatives (terrorists or their victims) was indistinguishable. The incident exemplified the contested notion of what the Ulster Unionist Party described as 'genuine victims of terrorism'. A further question for the researchers was therefore whether the shorthand everyday usage of these terms, which has a 
practical convenience and is easily comprehended in fieldwork, compounds their inherent ambiguity, disempowers survivors and reinforces politicization.

Aside from the sensitivities involved in the discourse of research, some attention is needed to the language and structuring of research terminology. It is too easy, for example, to adopt an uncritical use of the term 'community' or, more likely, 'the two communities' in Northern Ireland. Yet this kind of readily accessible description ignores conceptual difficulties with this notion, ranging from 'community' as a fiercely contested term to those who argue that what is meant by 'community' is self-evident (Hillery, 1955; Bell and Newby, 1971; Cohen, 1985; Midgely, 1986; Jewes and Murcott, 1996, 1998). For some, community refers to a defined locality or geographical area; for others, a local social system or set of relationships centred in a particular locality; more broadly, it denotes a sense of common identity based on shared interests or experiences which are not necessarily geographically based (Alcock et al., 1998: 396). The increasing polarization of unionists and nationalists, loyalists and republicans (which, in itself, defies the two communities' shorthand) into separate areas of Northern Ireland provides some geographical basis for community identity. On the other hand, even within the so-called 'loyalist' community there are a number of factional interests exemplified by the various paramilitary groups such as the Ulster Volunteer Force (UVF), the Ulster Freedom Fighters (UFF) - a cover name for the Ulster Defence Association (UDA) - the Red Hand Commandos (RHC) and the Loyalist Volunteer Force (LVF). Hence, being 'Protestant' does not of itself denote a sense of common identity and its distillation as one of the "two communities' must be treated with caution in undertaking research - the same is true when discussing Catholics, nationalists and republicans.

\section{Personal security}

The personal security risks associated with this type of research are patently high. Lee (1993), referring to Yancey and Rainwater (1970), described two kinds of danger that may arise during the research process: the 'presentational' and the 'anonymous'. The former arises when the researcher's presence or actions evoke aggression, hostility or violence within the setting. The latter, when the researcher is exposed to otherwise avoidable danger simply because of the dangerous research environment. Both kinds of dangers apply to studying paramilitary violence. Paramilitaries in Northern Ireland are well practised in dealing with 'touts' or those passing information, alleged or otherwise, to the RUC. This extends to those 'speaking out' against them. Suspected informers are shot, there are no exemption clauses for academic researchers. Former member of the PIRA, Eamon Collins, was murdered in January 1999 following his evidence against erstwhile PIRA associates in court and his authorship of a book revealing their operations and depiction of its members as 'a sadistic conspiracy of ageing, pot-bellied 
drink-induced egos'. Of more direct relevance to this research was the attempted assassination of Queen's University Professor of Comparative Politics, Adrian Guelke, in September 1991. The Ulster Freedom Fighters (UFF) broke into his home in Belfast and shot him in the side but failed to kill him because their guns jammed. The terrorists claimed that he was an intelligence officer for the IRA and involved in importing arms from the Middle East. It subsequently transpired from a journalist's investigation that Professor Guelke's South African background and research on violence therein had led to loyalist paramilitaries being approached. He was, he suspects, set up by an outsider. Guelke (1998) explained:

How or why I fell foul of some person in South Africa to the extent that I became a target for assassination I do not know. Perhaps my writing about South Africa's supply of arms to Loyalist paramilitary organisations gave offence, or a brief investigation I carried out into extreme right-wing violence in South Africa may have been the cause. There were a number of possibilities. From my experience of Northern Ireland I know how utterly trivial the reasons someone becomes a target can be. In general, campaigns of violence are rarely conducted with precision, whatever their ultimate purpose (p. 196).

Guelke's first-hand experience provides an ominous warning against complacency in undertaking fieldwork into paramilitary violence. A surveillance network operates with the task of 'keeping their eyes open' for unusual activity on behalf of the paramilitaries. Suspicion of the researchers' motives may not arise solely from paramilitaries. The security forces may have concerns about researchers being spies with no known or obvious connection to paramilitaries.

Suspicion of 'outsiders' is intense in this type of research and the perceived religion of the researcher is likely to be a key factor in the minds of interviewees. They will look for 'clues' to religious affiliation, which has become intrinsic to social interaction in Northern Ireland. The most obvious, although not failsafe, is the researcher's name. Beyond that, area of residence, birthplace, accent/language, appearance, school attended, interest in particular sports and, somewhat bizarrely, whether one is 'Catholic or Protestant-looking' (Burton, 1978). Coming from the 'other' community may condition the response of interviewees or put the researcher at some risk given the sensitive topic under review and the nature of the questions posed. To understand paramilitary 'policing' in Northern Ireland requires probing questions about motives, methods, support for paramilitaries' actions within their communities, and the exploration of alternative ways of dealing with anti-social behaviour. To the suspicious interviewee this may smack of information gathering reinforced by our preference to tape-record the interview for the purposes of data analysis.

It is only sensible in undertaking fieldwork to observe cautious security protocol. Being aware of the constituency in which one is interviewing is crucial - staunchly loyalist and republican enclaves are dotted throughout 
most towns/cities in Northern Ireland. Sensible security planning can involve working out entry and exit routes, opting, where possible, for safe(ish) locations to conduct interviews (e.g. administrative headquarters of political parties linked to paramilitaries), taking taxis to venues as opposed to using personal transport with car registration details, doing fieldwork in pairs, informing other members of the research team of your schedule. Whilst highlighting the importance of sensible personal security measures, these must be kept in perspective. Here we concur with Punch (1989), that researchers of controversial topics must not 'become over-sensitive so as to avoid dubbing the setting or topic virtually unresearchable' (cited in Brewer, 1993: 142).

\section{Conclusion}

Our experience gained in researching paramilitary violence in Northern Ireland demonstrates a need for measured sensitivity. The dearth of empirical work, which explores the complexities of the community-paramilitary relationship, makes this a worthwhile research topic. The concomitant methodological difficulties have no doubt contributed to the paucity of literature that, in itself, makes the study even more interesting. Difficult-toaccess subjects present new challenges for social scientists that may be situation-specific. Measured sensitivity, however, requires an awareness of the inherent dangers, whilst at the same time a flexibility in approach to problems which present themselves in the field. Managing issues of disclosure, sensitivity of language and perceived identification with all parties are crucial to such research. To ignore the obvious dangers would not only place the researcher at risk but would also be unlikely to secure the data necessary to investigate the phenomenon under study. What is clear from our work is that the pace of the research is less easy to dictate. Access can prove to be both time-consuming and restricted. Researching those subject to paramilitary 'punishment' to understand better the nature of such violence is difficult. There are relatively few gatekeepers and their priorities rarely coincide with the aims of the research. This may lead to compromise on research design. A quota sampling framework of interviewees, for example, is an unrealistic goal when access is so tightly controlled. Building trust with gatekeepers is crucially important to gaining access. This takes time. Thereafter researchers must demonstrate their independence in dealing with interviewees whose sensitivities are acute and where the researchers' motives are constantly under scrutiny.

Ethical issues in dealing with victims must underpin the research strategy. It is too easy to ignore the potential for exposing participants to physical and mental harm in areas of human suffering perpetrated within a volatile political context. Extreme care is therefore needed in data gathering, storage and usage. More generally, undertaking research in violent settings presents 
a dilemma for fieldworkers. To become too closely associated with research in one community (notwithstanding the problems with this term) may, by extension, cause alienation in another. As Jenkins (1993) suggests, the sole use of ethnography as a methodological tool may be limiting in these circumstances. What becomes crucial, if the work is not to become exclusive to one geographic area or ethnic community, is to establish research legitimacy by allaying natural suspicions about the motives of the work, establishing the bona fides of the researchers, being open and transparent about the research process and observing the sensitivities of language. This article highlights the fine line that researchers tread in conflict settings between concealment, in the interests of interviewees' co-operation, and deception. It also raises ethical concerns about the role of victims in the research process. The importance of their contribution, set alongside the difficulties in gaining access to them, can result in an unconscious disregard for their interests. Ethical concerns for informants may be negatively correlated to difficulties in securing access and their co-operation in the research.

\section{NOTES}

1. The figures show that loyalists were responsible for 43 percent of the shootings and 46 percent of the beatings, republicans carried out the remainder.

2. We deliberated over payments-for-access in our project and decided to reimburse interviewees at a standard rate for expenses incurred in attending (e.g. travel costs, child-minding fees, lost earnings).

\section{ACKNOWLEDGEM ENTS}

This research was funded under the ESRC Violence Research Project (Grant L133251003). The author wishes to acknowledge the research assistance of Dermot Feenan and Rachel Monaghan with aspects of the fieldwork. Useful comments were also received from Brice Dickson, Patricia Mallon and three external referees.

\section{REFERENCES}

Alcock. P., Erskine, A. and May, M. (1998) (eds) Social Policy Companion. Oxford: Blackwell.

Alty, A. and Rodham, K. (1998) 'Pearls, Pith and Provocation: The Ouch! Factor: Problems in Conducting Sensitive Research', Qualitative Health Research 8: 275-82.

Beattie, G. and Doherty, K. (1995) “'I Saw What Really Happened”: The Discursive Construction of Victims and Perpetrators in First Hand Accounts of Paramilitary Violence in Northern Ireland', Journal of Language and Social Psychology 14: 408-33.

Belfast Agreement (1998) The Agreement Reached in Multi-Party Negotiations. Belfast: Northern Ireland Office.

Bell, C. and Newby, H. (1971) Community Studies. London: Allen and Unwin.

Brewer, J. D. (1993) 'Sensitivity as a Problem in Field Research: A Study of Routine Policing in Northern Ireland', in C. Renzetti and R. Lee (eds) Researching Sensitive Topics. London: Sage. 
Brewer, J. D., Lockhart, B. and Rodgers, P. (1998) 'Informal Social Control and Crime Management in Belfast', The British Journal of Sociology 49: 570-85.

Burton, F. (1978) The Politics of Legitimacy: Struggles in a Belfast Community. London: Routledge \& Kegan Paul.

Cavanaugh, K.A. (1997) 'Interpretations of Political Violence in Ethnically Divided Societies', Terrorism and Political Violence 9: 33-54.

Cohen, A.P. (1985) The Symbolic Construction of Community. London: Routledge.

Fay, M.T., Morrissey, M. and Smyth, M. (1999) Northern Ireland's Troubles: The Human Costs. London: Pluto Press.

Feldman, A. (1991) Formation of Violence: The Narrative of the Body and Political Terror in Northern Ireland. Chicago: University of Chicago Press.

Fielding, N. (1990) 'Mediating the Message: Affinity and Hostility in Research on Sensitive Topics', American Behavioral Scientist 33: 608-20.

Guelke, A. (1998) The Age of Terrorism and the International Political System. London: I.B. Tauris.

Hillery, G.A. (1955) ‘Definitions of Community’, Rural Sociology 20: 111-24.

Hillyard, P. (1985) 'Popular Justice in Northern Ireland: Continuities and Change', in S. Stitzer and A.T. Scull (eds) Research in Law Deviance and Social Control, 7 London: Jai Press.

Jenkins, R. (1984) 'Bringing It All Back Home: An Anthropologist in Belfast' in C. Bell and H. Roberts (eds.) Social Researching: Politics, Problems and Practice. London: Routledge \& Kegan Paul.

Jenkins, R. (1993) 'Beyond Ethnography: Primary Data Sources in the Urban Anthropology of Northern Ireland', in C. Curtin, H.Donnan and T. Wilson (eds) Irish Urban Cultures. Belfast: Institute of Irish Studies.

Jewes, R.K. and Murcott, A. (1996) 'Meanings of Community', Social Science and Medicine 43: 555-63.

Jewes, R.K. and Murcott, A. (1998) 'Community Representatives: Representing the Community', Social Science and Medicine 46: 843-58.

Kennedy, L. (1995) 'Nightmares within Nightmares: Paramilitary Repression within Working-Class Communities', in L. Kennedy (ed.) Crime and Punishment in West Belfast. Belfast: Summer School, West Belfast.

Lee, R. (1993) Doing Research on Sensitive Topics. London: Sage.

Lee, R. (1995) Dangerous Fieldwork. Thousand Oaks, CA: Sage.

MacKay, A. (1999) 'Terrorist Mutilations (Northern Ireland)', House of Commons Hansard Debates, 27 January.

McGarry, J. and O'Leary, B. (1995) Explaining Northern Ireland: Broken Images. Oxford: Blackwell.

Midgely, J. (1986) (ed.) Community Participation, Social Development and the State. London: Methuen.

Murray, R. (1982) ‘Political Violence in Northern Ireland 1969-1977', in F.W. Boal and J.N.H. Douglas (eds) Integration and Division: Geographical Perspectives on the Northern Ireland Problem. London: Academic Press.

Nolan, P.C., McPherson, J., McKeown, R., Diaz, H. and Wilson, D. (1999) 'The Price of Peace: The Personal and Financial Cost of Paramilitary Punishments in Northern Ireland', unpublished paper, Belfast, Royal Victoria Hospital.

Northern Ireland Office (2000) Fear of Crime and Victimisation in Northern Ireland. Belfast: Criminal Justice Policy Division - Northern Ireland Office.

O’Duffy, B. (1995) 'Violence in Northern Ireland 1969-1994: Sectarian or EthnoNational?', Ethnic and Racial Studies 18: 740-72. 
Police Authority for Northern Ireland (PANI) (1999) Listening to the Community: Working with the RUC. Belfast: PANI.

Poole, M. (1993) 'The Spatial Distribution of Political Violence in Northern Ireland: An Update to 1993', in A. O'Day (ed.) Terrorism's Laboratory: The Case of Northern Ireland. Aldershot: Dartmouth.

Punch, M. (1989) 'Researching Police Deviance', British Journal of Sociology 40: $177-204$.

Silke, A. (1998) 'The Lords of Discipline: The Methods and Motives of Paramilitary Vigilantism in Northern Ireland', Low Intensity Conflict and Law Enforcement 7(2): 121-56.

Silke, A. (1999) 'Rebel's Dilemma: The Changing Relationship between the IRA, Sinn Féin and Paramilitary Vigilantism in Northern Ireland', Terrorism and Political Violence 11(1): 55-93.

Sluka, J.A. (1989) Hearts and Minds, Water and Fish: Support for the IRA and INLA in a Northern Irish Ghetto. Greenwich, CT: JAI Press.

Sullivan, S. (1998) 'From Theory to Practice: The Patterns of Violence in Northern Ireland 1969-1994', Irish Political Studies 13: 76-99.

Sutton, M. (1994) An Index of the Deaths from the Conflict in Ireland 1969-1993. Belfast: Beyond the Pale.

Thornton, C. (1999) 'Victim's Sister Slams Ingram for Talks with IRA Relatives', Belfast Telegraph, 25 January: 6.

Tunnell, K.D. (1998) 'Honesty, Secrecy and Deception in the Sociology of Crime: Confessions from the Backstage', in J. Ferrell and M. Hamm (eds) Ethnography at the Edge: Crime, Deviance and Field Research. Boston, MA: North-Eastern University Press.

White, R.W. (1993) 'On Measuring Political Violence: Northern Ireland, 1969 to 1980', American Sociological Review 58: 575-85.

Whyte, J. (1990) Interpreting Northern Ireland. Oxford: Clarendon Press.

Yancey, W. and Rainwater, L. (1970) 'Problems in the Ethnography of Urban Underclasses', in R. W. Habenstein (ed.) Pathways to Data. Chicago: Aldine.

COLIN KNOX is Professor of Public Policy at the University of Ulster in Northern Ireland. His research interests are in public administration reform and conflict resolution and his most recent book is Conflict Resolution at the Micro Level: Northern Ireland, Israel and South Africa (Macmillan, 2000).

Address: School of Public Policy, Economics and Law, University of Ulster, Shore Road, Jordanstown, Northern Ireland BT 37 OQB, UK. [email: cg.knox@ulst.ac.uk] 